Gut, 1981, 22, 953-957

\title{
Effect of cholera toxin on ileal water and solute transport after resection of the proximal small intestine in the rat*
}

\author{
W F TOWNSEND, L G WALTER, J L KINZIE, AND H V AMMON† \\ From the Department of Medicine, Veterans Administration Center, Wood (Milwaukee), \\ Wisconsin and The Medical College of Wisconsin, Milwaukee, Wisconsin, USA
}

SUMMARY Intestinal adaptation after extensive small bowel resection results in mucosal hypertrophy and an increased capacity of the remaining small intestine to absorb solutes and water. We tested the ability of the adapted rat ileum to respond to a secretory stimulus, cholera toxin. Six weeks after $50 \%$ jejunal resection (short gut) or sham operation water and solute transport were measured in a $16 \mathrm{~cm}$ segment of ileum before and after exposure to cholera toxin in a single pass in vivo perfusion system. During the control periods absorption of glucose, acetate and water per unit length of intestine was significantly greater in short gut animals $(\mathrm{P}<0.05$ to 0.001$)$. After exposure to cholera toxin absorption of glucose and acetate was significantly reduced in both groups $(\mathrm{P}<0.05$ to 0.01$)$. Sodium and chloride secretion and net change in water movement in response to cholera toxin were significantly greater $(\mathrm{P}<0.05$ to 0.01$)$ in short gut animals. Generally the differences between short gut and sham operation animals disappeared when the data were normalised for mucosal weight. Chloride secretion per gram mucosa was less in short gut animals $(\mathbf{P}<0.001)$. The data indicate that the adapted small bowel is not only capable of enhanced absorption but also of enhanced net secretion in response to cholera toxin. The changes reflect the increased number of enterocytes per unit length of intestine after intestinal adaptation.

Intestinal adaptation after extensive small bowel resection is characterised by increased villous height, ${ }^{1-3}$ crypt cell proliferation, ${ }^{34}$ and enhanced ability for solute ${ }^{135}$ and water $^{6}$ absorption in the remaining small intestine. As the mucosal surface is enlarged by the process of adaptation, one would expect that the remaining intestine is not only capable of enhanced absorption but that it should also respond with enhanced secretion of electrolytes and water when exposed to a secretory stimulus. Here we report studies of water and solute transport in the adapted small bowel of the rat before and after exposure to cholera toxin. The results are

*This paper was presented in part at the Annual Meeting of The American Gastroenterological Association in Las Vegas, Nevada, May 1978 and has been published in abstract form (Gastroenterology 1978, 74: 1106).

†Address for requests for reprints: Dr Helmut V Ammon, Gastroenterology Section/111C, Veterans Administration Medical Center Wood (Milwaukee), Wisconsin 53193, USA.

Received for publication 7 May 1981 compared with the response in sham operated animals.

\section{Methods}

ANIMAL MODEL

Male Sprague-Dawley rats (Holtzman Co., Madison, WI) weighing 235-260 g, underwent surgery under general anaesthesia with pentobarbitone and ether. The operation was either a simple laparotomy (sham operated rats) or a resection of $50 \%$ of the small intestine starting at the ligament of Treitz with an end-to-end jejunoileal anastomosis (short gut rats). Postoperatively the animals were maintained on a full-strength liquid element diet (Flexical, Meade-Johnson, Evansville, Indiana) with free access to water. Six weeks after surgery perfusion studies were performed under general anaesthesia after an overnight fast. A $16 \mathrm{~cm}$ segment of small intestine with its distal end $5 \mathrm{~cm}$ proximal to the ileocaecal valve was isolated, with its blood supply 
intact, cannulated, rinsed with $0.9 \% \mathrm{NaCl}$, and returned to the abdomen. The segment was perfused in a single pass at $1 \mathrm{ml} / \mathrm{min}$. The temperature of the animals was maintained at $37^{\circ} \mathrm{C}$ with a heat lamp controlled by a rectal thermometer.

\section{EXPERIMENTAL DESIGN AND COMPOSITION} OF PERFUSION SOLUTIONS

Each experiment consisted of five one hour perfusion periods. Two test solutions, $\mathrm{A}$ and $\mathrm{B}$, were perfused for one hour before and after exposure of the test segment to cholera toxin. The perfusion sequence, therefore, was always $\mathrm{A}-\mathrm{B}$-exposure to cholera toxin-A-B; each one hour perfusion period consisted of a 20 minute equilibration period and two 20 minute sampling periods. Solution A contained in mmol/l: $\mathrm{Na} 50, \mathrm{~K} 2 \cdot 5, \mathrm{Cl} 2 \cdot 5$, acetate 50 , polyethylene glycol 4000 (PEG-4000) $10 \mathrm{~g} / \mathrm{l}$, ${ }^{14} \mathrm{C}-\mathrm{PEG}$ (New England Nuclear, Boston, Mass.) $10 \mu \mathrm{Ci} / \mathrm{l}$ and mannitol to an osmolality of 300 $\mathrm{mOsm} / \mathrm{l}$. $\mathrm{pH}$ was $7 \cdot 4$. Solution B differed from solution $\mathrm{A}$ by the addition of $10 \mathrm{mmol} / \mathrm{l}$ glucose and a corresponding reduction in mannitol concentration. Exposure to cholera toxin was accomplished by recirculating $25 \mathrm{ml} 0.9 \%$ saline containing $250 \mu \mathrm{g}$ cholera toxin (Wyeth, NIH Lot 0172) at $1 \mathrm{ml} / \mathrm{min}$ for one hour. After completion of the experiment the test segments were excised, weighed and the ex vivo length measured under tension of a $5 \mathrm{~g}$ weight. The mucosa of the central $4 \mathrm{~cm}$ of each test segment was stripped and weighed with the assumption that it was representative of the entire test segment.

\section{ANALYTICAL METHODS}

PEG was determined as ${ }^{14} \mathrm{C}-\mathrm{PEG} .{ }^{2}$ For the isotope determination, $1 \mathrm{ml}$ of the perfusion solution or collected samples was mixed with $10 \mathrm{ml}$ of a scintillation of cocktail composed of toluene and emulsifier (Ready Solv HP, Beckman Instruments, Inc., Fullerton, CA) and counted in a liquid scintillation counter (Beckman, model LS-255). Quench correction was made by external standardisation. Sodium and potassium were measured by flame photometry, chloride by electrometric titration with a silver nitrate solution and glucose by the glucose oxidase method (Boehringer Mannheim Corp., New York, NY). Acetate was measured by gas liquid chromatography ${ }^{8}$ (Gaschromatograph: Varian 3700 with flame ionisation detector). To $1 \mathrm{ml}$ of the samples $50 \mu \mathrm{l} 400 \mathrm{mM}$ sodium isobutyrate were added as an internal standard. After vortex mixing, 2 drops of concentrated $\mathrm{HCl}$ (approximately $500 \mu \mathrm{mol}$ ) were added and the sample immediately closed with a stopper. Analysis was carried out on a glass column (200 cm long, $2 \mathrm{~mm}$ internal diameter) packed with
$10 \%$ AT-100 on $80 / 100$ Chromasorb W-AW (Alltech Assoc., Arlington Heights, IL). Column temperature was $125^{\circ} \mathrm{C}$ (isothermal). Peak areas were determined with a digital integrator. Linear dose responses for acetate were obtained under these conditions over a range from $0-100 \mathrm{mmol} / \mathrm{l}$.

CALCULATIONS AND STATISTICAL ANALYSIS

Net water and solute movements were calculated by standard formulas using the measured PEG and solute concentrations. ${ }^{9}$ Steady state conditions were confirmed by comparing the PEG concentrations during the first and second 20 minute sampling periods within each perfusion period. No significant differences were observed. The mean of the two consecutive 20 minute sampling periods, therefore, was used as one data point. The data were normalised for segment length of intestine or mucosal weight. Paired and unpaired $t$ tests were used for statistical analysis. All data are reported as means \pm SE.

\section{Results}

Sham operated $(n=5)$ and short gut $(n=6)$ animals gained $35+2 \mathrm{~g}$ and $33+3 \mathrm{~g}$ respectively during the six weeks after surgery and weighed $285 \pm 3 \mathrm{~g}$ and $278 \pm 6 \mathrm{~g}$ at the time of study. The ex vivo length of the test segments was $16.2 \pm 1.5 \mathrm{~cm}$ in the sham operated group and $17.0 \pm 0.7 \mathrm{~cm}$ in the short gut group (NS). The test segments weighed $47 \cdot 4 \pm 1 \cdot 6$ $\mathrm{mg} / \mathrm{cm}$ in the sham operated animals and $76 \cdot 3 \pm 3 \cdot 8$ $\mathrm{mg} / \mathrm{cm}$ in the short gut animals $(\mathrm{P}<0.005)$. The mucosal weight was $14 \cdot 2 \pm 0.8 \mathrm{mg} / \mathrm{cm}$ and $26.5+1.9$ $\mathrm{mg} / \mathrm{cm}$ respectively $(\mathrm{P}<0.005)$.

Net WATER MOVEMENT (Table 1)

Short gut animals absorbed water at a faster rate than sham operated animals under control conditions $(\mathrm{P}<0.05-0 \cdot 025)$. Exposure to cholera toxin resulted in net fluid secretion under all test conditions. During perfusion of solution B net fluid secretion in short gut animals was greater than in sham operated animals but the difference failed to reach statistical significance $(P<0 \cdot 1)$. The total change in water movement under the influence of cholera toxin was significantly greater in short gut animals during perfusion of solution A $(P<0.05)$ and $\mathrm{B}(\mathrm{P}<0.01)$.

ABSORPTION OF GLUCOSE AND ACETATE (Table 2)

As the changes in solute absorption induced by cholera toxin were essentially the same for solution $A$ and $B$ we report here only the data obtained during perfusion of solution $\mathbf{B}$. Glucose and acetate 
Table 1 Net water movement in sham operated and short gut rats in response to cholera toxin $(\mu l / \mathrm{cm} / \mathrm{h} ; \mathrm{mean} \pm S E)^{*}$

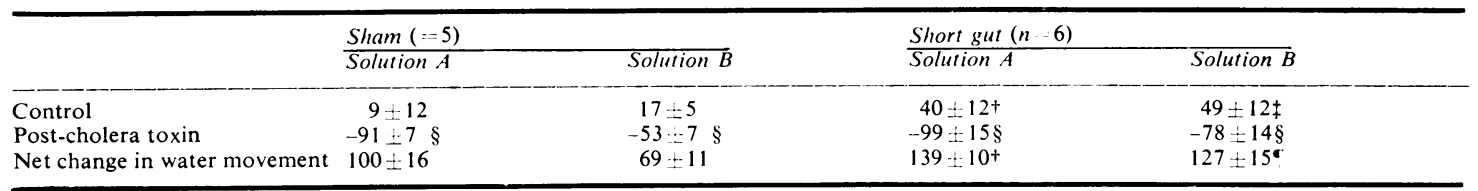

* Minus signs indicate net secretion.

$\dagger \quad P<0.05$ vs sham.

$\ddagger \quad \mathrm{P}<0.025$ vs sham.

$\S \quad \mathrm{P}<0.0025$ vs control.

- $P<0.01$ vs sham.

$16 \mathrm{~cm}$ of ileum were perfused with solution A (no glucose) and B (10 m M glucose) for 1 hour before and after exposure to cholera toxin (one hour).

Table 2 Net solute transport in sham operated and short gut rats in response to cholera toxin $(\mu \mathrm{mol} / \mathrm{cm} / \mathrm{h} ; \mathrm{mean} \pm S E)^{*}$

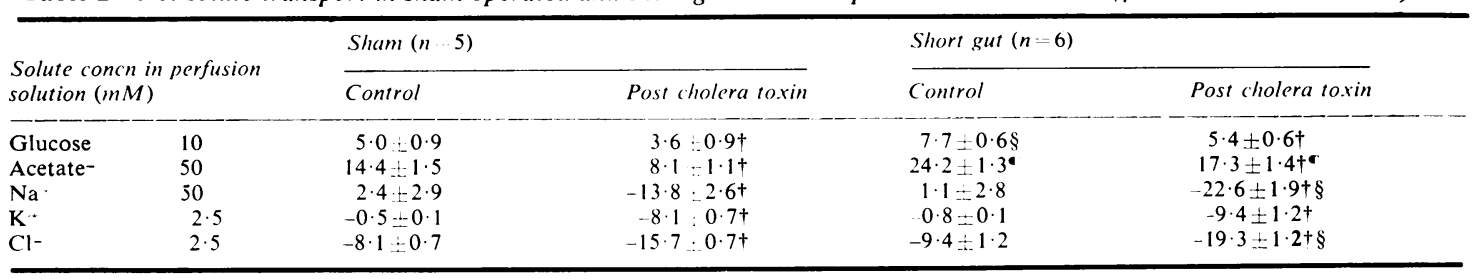

* Minus signs indicate net secretion.

$+\quad P<0.01$ vs control.

$\ddagger \quad P<0.05$ vs control.

$\$ \quad \mathrm{P}<0.05$ vs sham.

- $P<0.001$ vs sham.

Experimental conditions as in Table 1. The data were obtained during perfusion of solution $\mathbf{B}$.

absorption during the control periods was significantly greater in short gut animals than in sham operated animals $(\mathrm{P}<0.05$ and $\mathrm{P}<0.001$ respectively). When normalised for mucosal weight, glucose absorption was $0.30-0.03 \mu \mathrm{mol} / \mathrm{mg} / \mathrm{h}$ in short gut animals and 0.37:0.07 $\mu \mathrm{mol} / \mathrm{mg} \mathrm{h}$ in sham operated animals (NS). Acetate absorption normalised for mucosal weight was $0.92 \div 0.05$ $\mu \mathrm{mol} / \mathrm{mg} / \mathrm{h}$ and $1.05=0.15 \mu \mathrm{mol} / \mathrm{mg} / \mathrm{h}$ respectively (NS). After exposure to cholera toxin glucose absorption decreased significantly in sham operated $(\mathrm{P}<0.01)$ and short gut animals $(\mathrm{P}<0.01)$. Similarly, acetate absorption decreased significantly in sham operated $(\mathrm{P}<0.05)$ and short gut animals $(\mathrm{P}<0.01)$. The glucose concentration in the effluent in sham operated rats was $8.1=0.2 \mathrm{mM}$ in the control period and $8 \cdot 3+0 \cdot 2 \mathrm{mM}$ after exposure to cholera toxin. The corresponding data in short gut animals were at $7.5: 0.1 \mathrm{mM}$ and $7 \cdot 8: 0.1 \mathrm{mM}$ respectively.

ELECTROLYTE TRANSPORT (Table 2)

Under control conditions, sodium absorption was equal in both groups. After exposure to cholera toxin net sodium secretion was significantly greater in the short gut animals $(\mathrm{P}<0.02)$. When sodium transport was normalised for mucosal weight, sodium absorption was $0 \cdot 18=0.22 \mu \mathrm{mol} \mathrm{mg} \mathrm{h}$ in sham operated and $0.02=0.11 \mu \mathrm{mol} \mathrm{mg} / \mathrm{h}$ in short gut animals (NS). The net secretion rates for sodium after exposure to cholera toxin were $-0.97+0.19 \mu \mathrm{mol} / \mathrm{mg} / \mathrm{h}$ in short gut and $-0.87 \div 0 \cdot 1$ $\mu \mathrm{mol} / \mathrm{mg} / \mathrm{h}$ in sham operated animals (NS). There was no difference between short gut and sham operated animals with respect to the net potassium movement. After exposure to cholera toxin, potassium absorption changed to potassium secretion $(P<0.01)$. Both groups of animals secreted chloride under control conditions to an equal degree. After exposure to cholera toxin, chloride secretion increased. The net secretion rate was significantly greater in the short gut animals $(\mathrm{P}<0.05)$. When the data were normalised for mucosal weight, chloride secretion after exposure to cholera toxin was $-1.11 .0 .02 \mu \mathrm{mol} / \mathrm{mg} / \mathrm{h}$ in sham operated animals and $-0.74 \div 0.06 \mu \mathrm{mol} / \mathrm{mg} / \mathrm{h}$ in short gut animals $(\mathrm{P}<0.001)$.

\section{Discussion}

The animals were truly adapted as indicated by the increased mucosal weight and the increased absorption of glucose, acetate, and water. The composition of the perfusion solutions was chosen with a second set of experiments in mind, which are not part of this report. The rather low sodium concentration 
in the perfusion solutions, however, distorted the outcome of the studies somewhat. It resulted in low sodium absorption rates and chloride secretion ${ }^{10}$ under control conditions and abolished any differences in sodium absorption between short gut and sham operated animals that might have been otherwise apparent. Because the perfusion solutions contained large amounts of readily absorbable organic solutes, water absorption was supported by the absorption of acetate ${ }^{11}$ and glucose ${ }^{12}$. Thus, the increased absorption of glucose and acetate in the short gut animals explains the enhanced absorption of water in this group. As solute transport followed a downhill concentration gradient, no concomitant changes in sodium absorption occurred. ${ }^{13}$

The observation that glucose and acetate absorption decreased after exposure to cholera toxin is at variance with earlier reports which state that glucose absorption is not affected in the presence of fluid secretion induced by cholera toxin ${ }^{14} 15$. The results reported here are not an artefact due to the composition of the perfusion solutions because we observed similar results when we perfused solutions containing $150 \mathrm{mM} \mathrm{NaCl}{ }^{16}$ In addition, Rhode and $\mathrm{Chen}^{17}$ observed a reduction in the absorption of arabinose and urea in the presence of fluid secretion induced by cholera toxin.

The experiments demonstrate that the adapted small bowel is not only capable of increased solute and water absorption, but that it can also respond with increased sodium and chloride secretion to a secretory stimulus, such as cholera toxin. As is true for enhanced solute absorption, ${ }^{35}$ this effect reflects the increased number of enterocytes, as the difference between sham operated and short gut animals generally disappears when the data are normalised for mucosal weight. The reduced response in chloride secretion per $\mathrm{mg}$ mucosal weight in the short gut animals is more difficult to explain. In view of the artificially low chloride concentration a conclusive statement is not possible.

Although the greater secretion rates for sodium and chloride demonstrate the enhanced capacity of the adapted small bowel for electrolyte secretion in response to cholera toxin, net secretion rates for water in the short gut animals were not significantly different from the controls. This blunting of the net secretory response is probably the result of the composition of our perfusion solutions, which provided large amounts of absorbable solutes which enhanced water absorption. ${ }^{112}$ This interpretation is supported by the fact that solute absorption after cholera toxin remained greater in the short gut animals and by the fact that the net change in water movement in the response to cholera toxin was also significantly greater in these animals (Table 1). The studies, therefore, provide evidence that the adapted small bowel is not only capable of enhanced absorption but also of enhanced electrolyte and fluid secretion in response to cholera toxin and, presumably, other secretory stimuli.

This study was supported by the Medical Research Service of the Veterans Administration and by a Research Grant AM 17941 from the National Institutes of Health, US Public Health Service. The authors wish to thank Mr Peter Kotvis for excellent technical help.

\section{References}

${ }^{1}$ Dowling RH, Booth CC. Structural and functional changes following small intestinal resection in the rat. Clin Sci 1967; 32:139-49.

'Weser E, Hernandez MH. Studies of small bowel adaptation after intestinal resection in the rat. Gastroenterology 1971; 60:69-75.

${ }^{3}$ Menge $\dot{H}$, Robinson JWL. The relationship between the functional and structural alterations in the rat small intestine following proximal resection of varying extents. Res Exp Med 1978; 173:41-53.

${ }^{4}$ Hanson WR, Osborne JW. Epithelial cell kinetics in the small intestine of the rat 60 days after resection of $70 \%$ of the ileum and jejunum. Gastroenterology 1971; 60: 1087-97.

"Garrido AB, Freeman HJ, Chung YC, Kim YS. Amino acid and peptide absorption after proximal small intestinal resection in the rat. Gut 1979; 20:114-20.

${ }^{6}$ Weinstein LD, Shoemaker CP, Hersh T, Wright HK. Enhanced intestinal absorption after small bowel resection in man. Arch Surg 1969; 99:560-2.

'Wingate DL, Sandberg RJ, Phillips SF. A comparison of stable and ${ }^{14} \mathrm{C}$-labelled polyethylene glycol as volume indicators in the human jejunum. Gut 1972; 13:812-5. ${ }^{*}$ Alltech Associates, Inc: Chromatography' supplies. Catalog 1977; 26:14.

${ }^{9}$ Wingate DL, Krag E, Mekhjian HS, Phillips SF. Relationships between ion and water movement in the human jejunum, ileum and colon during perfusion with bile acids. Clin Sci Mol Med 1973; 45:593-606.

${ }^{10}$ Turnberg LA, Bieberdorf FA, Morawski SG, Fordtran JS. Interrelationships of chloride, bicarbonate, sodium and hydrogen transport in the human ileum. J Clin Invest 1970; 49:557-67.

"Schmitt MG, Soergel KH, Wood CM. Absorption of short chain fatty acids from the human jejunum. Gastroenterolog. 1976; 70:211-5.

1 'Saltzman DA, Rector FC, Fordtran JS. The role of intraluminal sodium in glucose absorption in vivo. J Clin Invest 1972; 51 :876-85.

${ }^{1: 3}$ Fordtran J. Stimulation of active and passive sodium absorption by sugars in the human jejunum. $J$ Clin Invest 1975; 55:728-37. 
${ }^{14}$ Carpenter CCJ, Sack RB, Feeley JC, Steenberg RW. Site and characteristics of electrolyte loss and effect of intraluminal glucose in experimental canine cholera. $J$ Clin Invest 1968; 47:1210-20.

${ }^{15}$ Serebro HA, Bayless TM, Hendrix TR, Iber FL, McGonagle T. Absorption of d-glucose by the rabbit jejunum during cholera toxin-induced diarrhoea.
Nature 1968; 217:1972-3.

${ }^{16} \mathrm{Ammon} \mathrm{HV}$. An in vivo model for the effects of dihydroxy bile acids and fatty acids on intestinal transport processes. Clin Res 1980; 28:271 A.

${ }^{17}$ Rhode JE, Chen LC. Permeability and selectivity of canine and human jejunum during cholera. Gut 1972; 13:191-6. 